DOI 10.14746/ssp.2019.2.13

Beata PająK-PAtKowska

Adam Mickiewicz University

ORCID: 0000-0002-6509-8067

\title{
The activity of the Mamy Glos Foundation in the context of youth political activism
}

\begin{abstract}
This paper aims to examine the activity of the Mamy Głos Foundation [We have a voice], an organization founded in 2015 by junior high school students from a handful of towns in Poland. For this purpose, a review of available materials about this organization will be carried out and information will be collected using in-depth interviews with the founders of the organization. The main research question concerns the motivation behind young people's activity in the foundation, the methods used to achieve the goals of the organization and its founders' profiles. Their activity will be presented in the context of political activism among young people, including gender differentiation.
\end{abstract}

Key words: youth, Mamy Głos Foundation, political activism

\section{Young people as participants in political activity}

Y

oung people form a part of society that is frequently complained about due to their low level of political and social activity and lack of interest in socio-political issues. It may appear that development processes, especially in the 12-17 age bracket, make adolescence a period of rebellion and rejection of the adult world, which may additionally result in young people withdrawing into their private worlds. This group has not attracted particular interest from researchers, as studies concern young people aged 18-25 much more often. Still, a few interesting surveys can be found which give insight into political activism among this group of young people.

The group aged 11-17 was examined by Anna M. Zalewska and Beata Krzywosz-Rynkiewicz (2011), who attempted to analyze the relationship between developmental and individual factors and civic activism among young people, including political activity. This research demonstrated that the level of political activity (called conventional activity) is not gender- 
related. The only factor which affected this form of civic activity, among such variables as sex, age and the size of the niche, was the size of place of residence. Young people from smaller towns appeared more keen to undertake political activity in the future. Sex differences regarding the level of civic activity were demonstrated only with respect to passive citizenship (sense of national identity and patriotism) and social activism (e.g. fund raising, voluntary work, taking part in local campaigns). It can therefore be hypothesized that potential conventional activism gains significance in early adulthood.

\section{Characteristic features of adolescence - the psychological and developmental context of political and social activism}

In the context of the organization examined in this article, the stage of life of interest to us is adolescence, which is divided into two stages: early adolescence (age 12-16) and late adolescence (age 17-19). The Mamy Gtos Foundation was founded by girls in the early stage of adolescence, who targeted their activities at their peers.

The crucial feature of adolescence is that it marks the transition from childhood to adulthood, which is accompanied by a number of changes in various fields of an individual's life and activities.

Around the age of 12, formal thinking begins, allowing hypothetical and reflexive reasoning to be achieved (which is fully developed by the age of 20). This makes it possible to make plans for the future, perceive oneself in a broader social context and become ready to take on the role of worker and citizen. The development of formal thinking also makes it possible to comprehend social and political systems and see a broader perspective. At the same time, this period is marked by cognitive insecurity, mainly caused by increased awareness of multifarious factors which determine the course of different processes. That is why young people, especially in the second stage of adolescence, behave as if they have been deprived of their intellectual foundations.

The early adolescence period is additionally characterized by high emotional lability which may result in young people getting involved in numerous social activities which are quickly abandoned. With time, young people's behavior becomes increasingly stable. These changes allow them to perceive themselves as members of a larger community. In this period, they gradually transition from being members of a family 
community to being members of a social community, including a civic community; this transition is considerably easier when taking place within a peer group, which ensures a higher level of security.

This period is of utmost importance regarding the emergence of one's identity which is formed at this time. The initially strong need for autonomy and establishing partnership relationships with adults transforms into a greater degree of self-awareness, and becoming independent in one's judgements from those of one's environment. The feeling of maladjustment and alienation, which is associated with diffusion identity, is later replaced by the stage of adopting the opinions and conduct of individuals with authority (moratorium identity) to result in the emergence of a mature identity in the stage of late adolescence. This is the time when one's opinions become more flexible, as evidenced by increased openness to debating and confronting other points of view. Individual identity is also shaped during adolescence, which is currently impeded due to the changes in the modern world.

\section{Mamy glos - at the roots of developing female political awareness}

Mamy Gtos [We have a voice] is a foundation established and managed by five girls from Poznań and Zielona Góra. It promotes women's rights and history and strong female role models among teenagers. The foundation's areas of operation and related objectives featured on its website also encompass security and building the awareness of the rights and potential of junior and senior high school girls. This target group allows a somewhat neglected group of women to be addressed: "there are strong women's organizations in Poland working for women's rights. Yet we believe that support needs to be provided to girls much earlier. That is why we address our project at junior and senior high school girls."1 The foundation claims that "a majority of organizations and campaigns promoting women do not take the world of girls into account. Women's rights are discussed in the media in the context of reproductive rights, among other things, while there are more urgent topics for teenagers, such as online hate."

The foundation's founders emphasize the fact that the organization is open to everybody, both male and female, who pursues the principle of respecting dignity.

1 The quotes in this part are taken from the Mamy Głos website (http://mamyglos. com) and it's profile on Facebook (https://www.facebook.com/mymamyglos/). 
The beginnings of Mamy Gtos are related to the unequal treatment experienced by one of the foundation's members and founders - Kamila Gołdyka. It took her three months to change her education profile from humanities to technical studies, while her male colleague achieved the same within a single week. Despite having better grades, the girl had to take tests of competence and vocational preferences in order to prove that she was making the right choice. Later on, she heard her physics teacher joking on Friday that the girls should go home to cook dinner for their boyfriends.

The girls say that Mamy Głos was inspired by their being 'peed off' with the situation, and so they resolved to change the things they did not like. With a grant they had won in a contest for a non-governmental startup, organized by the Humanity in Action Polska and the Polish Association of Young Journalists, they made a video promoting their initiative. The recording features a range of teenagers of different types of beauty, origin and mobility, accompanied by a girl's voiceover saying "you have the right to be whatever girl and woman you want. You have the right to wear dresses or not to wear them. You have the right to become an astronaut. You have the right to think about your Prince Charming, a Princess, or about being on your own. You have the right to report rape to the police. You have the right to be tall, to have a boyfriend who is shorter than you, wear stilettos and still feel great." They say that these words reflect everything that they have always wanted to hear, but have never heard at home or at school.

The same message can be found in the declaration published on the foundation's website:

\#MamyGtos operates to show girls that they have the power, that they are great, gifted, beautiful and that they have immense potential! They have a voice and they do not have to be afraid to use it. Each and every one of us can be an engineer, cook, writer, scientist, footballer, Polish teacher, physician... We can be whatever we want, we have the right to make our dreams come true and we have the right to have our rights respected.

They carry on saying that

[w] want every girl in Poland to be safe at home, at school, in the street and in her own skin. Alongside thirty (female and male) activists we operate in several cities of Poland where we organize workshops to learn about activism, body positivity and self-defense, offer psychological advice and organize a variety of campaigns. 
This is because we are terrified by the statistics of violence against women and we see that school is one of the origins of this problem. On the one hand, teachers frequently scorn girls, and, on the other, textbooks and the books on the reading list do not present too many wonderful and strong women we could be inspired by in our professional and life choices.

It is therefore one of the objectives of the Mamy Glos to promote herstory, present historic events from the female point of view and emphasize the role of women in these events.

\section{Description of operations}

The girls organize themselves mainly via the internet. They use the group's website, Instagram and Facebook account to encourage new people to join their activities in a more or less active way. The first sentence on the "Join" (Włacz się) tab says:

Start by liking the posts on FB, insta and youtube. You think this is insignificant? Wrong! MamyGlos operates mainly online. Thanks to the internet people register for our workshops, and thanks to the internet our creations move on. Invite five friends to like our website. The more people follow us, the more likely it is that our message will reach someone who needs it.

What next? You can run workshops, be interviewed by the media, come to our events, find places where we can sell our coloring books, read books for us and review them, translate from English, fill in documents, draw, take interviews, record podcasts, take pictures, shoot videos, get things done in government offices, write applications for grants, and organize campaigns and events. Remember that even if you do not like to speak in front of crowds, you can still make your contribution in our events.

People who do not have time for such activities are encouraged to buy products featuring the logo of Mamy Gtos and to support the foundation financially.

In interviews, the activists repeatedly stress the fact that all of those active in the foundation are equal, and that there is a network of activists throughout the entire country (approximately 30 at present) cooperating in finding rooms for workshops and organizing a variety of events. All of them are aged 15-23. They say that when they want to acquire additional know-how, they ask for "help from older, experienced people." Their 
online activity reaches approximately 50,000 - sometimes up to 100,000 - individuals aged 13-25. They operate through social media because of their target group: "we know that teenagers are there every day and this is how we can reach them. We also have a blog on our website, which girls volunteer to write."

The internet, however, is only a tool for promoting their operations and developing a support network for their activities. In order to achieve their objectives of building strength and a sense of agency in young women, they organize workshops and meetings with inspiring females. Thanks to funds collected via the Internet, the foundation has also published a coloring book featuring the profiles of strong women in history who are often absent or marginalized in school and the media. The website additionally features contact details to reach psychologists collaborating with the foundation for girls aged 13-20 who might need their help. They can also contact the department for legal and psychological aid operating at the Women's Rights Center.

Despite having operated for a relatively short time, Mamy Głos has already made a number of achievements. First and foremost, the foundation's range of operations has expanded, which was reflected in the enlargement of the management team from three to six individuals, and in increasing its reach from one to five cities. Conducted activities encompass workshops in activism, assertiveness, self-defense, law, critical blog-writing, critical thinking, privileges, sensitive language and body positivity for a total of 900 individuals. As well as workshops and meetings organized under the MegaGals Meeting scheme and Breakfast Discussion Club, the organization has also succeeded in obtaining four grants (two from Humanity in Action, one from FRIDA - The Young Feminist Fund and one from the PISOP Center for the Promotion and Development of Civil Initiatives), organizing seven raffles combined with collecting money for hygiene products for women who need them, and a crowdfunding campaign for the publishing of a coloring book with MegaGals. They also propagate herstory on Facebook, making posts about important female characters such as the first female pilot, as well as about currently active women whose speeches are published. As well as being active online, the foundation organizes sticker campaigns (the V-Gang Sticker Club, the members of which pay 8 zlotys per month (around 2 euro) for which they get a batch of stickers and a letter) and co-organizes a national art contest for teenagers Afterimages with MegaGals. Mamy Głos has also attracted media coverage, and their activities have been described on the internet 
and in the media associated with feminist groups, as well as in the national media such as the Gazeta Wyborcza newspaper and Newsweek and Polityka weeklies.

The organization has also made 18 videos to inform girls about their rights.

Thanks to another grant received from Humanity In Action, Mamy Gtos have started the Girl Power Academy. Academy participants learn how (broadly understood) discrimination is present in the media, art and language, and how it affects the future lives of girls.

\section{Future plans}

The organization set the following objectives for 2018: to develop a network of Local Clubs in Polish cities, to organize an event for 2000 teenage girls, to publish a guidebook on activism and to issue a guidebook for victims of violence. In an interview, they also mentioned their plans to open a shop offering an extended range of their products: "alongside coloring books, backpacks, bags and stickers, we will design a variety of products with graphic designers willing to volunteer to work with us." Asked about their plans for the immediate future, they also talk about a nationwide tour promoting body positivity, in which fifteen workshops will be organized in various Polish cities. They also said that general interest in their workshops has been on the rise and approximately 60 schools have already submitted their requests from both female students and their teachers.

The above-mentioned book on activism will take a form of a guidebook, explaining how to not only start working for Mamy Gtos but how to become active in general. Another planned book is a handbook on psychology and law, written in language understandable to teenagers, telling them what to do if they have fallen victim to or witnessed violence. Another publication is a booklet on ecofeminism, and a "sisterhood game teaching cooperation rather than competition and showing that everybody wins only if we all win."

\section{Founders}

The activists of Mamy Głos include Kamila Gołdyka, Sylwia Wodzińska, Aleksandra Sobiech, Natalia Brodewicz and Weronika Zimna. The 
organization was founded by Kamila, Michalina Ferencz and Sylwia, who had met previously as girl scouts and during several activism campaigns.

Kamila Gołdyka is the girl whose experience of changing her educational profile from humanities to science inspired her to establish Mamy Głos. She says that "the situation I encountered in school came as a real shock to me, it was an eye-opener but it aggravated me first and foremost. After I talked to two friends from girl scouts, I realized we have all had similar experiences." ${ }^{2}$ She goes on to describe this experience as follows: "instead of complaining, we decided to do something constructive with our anger and this is when Mamy Gtos was born. I hadn't come across feminist ideology before, so you can say that I started by joining feminist circles and then began to discover them." Currently Kamila studies automation and robotics at the Warsaw University of Technology. She has a sister nine years her senior. Her parents have never been especially active socially or politically. Her mother, who did not even use to vote in elections, now joins her daughter for every feminist march or protest. Kamila admits that they talk a lot about politics at home, but when she was younger she was not involved in such discussions: "I was treated as a listener who gets told by her parents who she should vote for when she grows up." At present she enjoys her family's support for her involvement in Mamy Głos: "My father always half-jokingly says that it is better to be a feminist activist than to roam the streets."

Their peers were initially somewhat confused when Mamy Głos began.

In the back of their heads they had this image of feminists who shout, burn bras and do not shave their legs, and who cannot have boyfriends because they hate men. It took them some time to realize that their classmate, a warm and smiling girl, can also be a feminist. At the beginning, none of my friends openly said they were feminists. On the contrary, they repeatedly reassured everybody that they were not feminists by any means, to make sure that nobody will think ill of them. This situation has changed and the girls openly and proudly declare that they are feminists. I think that I was able to demystify the image of feminists in my environment.

My main motivation to become involved in Mamy Głos was my personal experience, mainly, but not only, in high school. The situ-

${ }^{2}$ All quotes in this part are taken from in-depth interviews conducted by Author with founders of MamyGlos in January and February 2018. 
ation I encountered at school was a real eye-opener. I had not been aware of inequality before; after all, I have lived all my life in society where nobody told me that it is not fair sometimes, and this makes it really tough on girls. As a young person, I was not very critical, I simply took everything at face value. I can describe what I experienced in high school as a wake-up call. It was only then that I began to notice how many things happen which I should not accept. For example, making jokes about girls in physics lessons, or the fact that our bodies are treated like projects which need constant improvement. I am sorry to say that, the older I get, the more reasons I see around me to work in Mamy Gtos. I can see how much remains to be done in practically every field.

For twelve years Kamila has been a girl scout, where she met the cofounders of the foundation. She would like to continue working for it for as long as possible, because she says it is fun for her. She describes herself as an idealist and an understanding, thorough and committed individualist.

Sylwia Wodzyńska is the oldest among the three founders. She was 27 years old when the foundation was established. She studied English, culture studies and sociology. She has a younger sister, who is a teenager now. Kamila's experience also made her aware of the existing inequalities. Nevertheless, she had experienced such inequalities herself, as well as violence from boys. However, this was always ignored by those around her, including the priest and school counsellor: "they always put the blame on me or embarrassed me, saying that that is what boys do and that the girls you argue with are the ones you like." She did not like it that the school did not teach about the women who have changed the world, or they were only shown through their relationships with men. She admits, however, that although she was socially involved, women's affairs were of no interest to her until the event experienced by her fellow girl scout: "I believed that when a woman is qualified and competent, she will manage. It was Kamila's case (I was 26 at the time) that made me realize that it was an uphill struggle for women. I began to read various reports, news, books, attended various events and became committed with all my heart to this cause."

Initially, her parents had a joking attitude to her involvement, while her religious grandmother "believed that feminism was the ultimate evil." She managed to persuade her parents to take part in protests and succeeded in changing her grandma's views. "This changed when I asked her what her life would have been like if she had known her rights when she 
was young. After all, violence is a common experience, whether you are a religious person or not." Her peers' response was usually calm. Sylwia knew how to stop people joking when she referred to police statistics. At one stage she began to hear that she was a radical. She felt awkward about this adjective being used with respect to her, but after a talk with the initiator of a feminist movement in Brazil she came to the conclusion that this might be the right description. "I realized then that I do not have to be furious to be radical, and that I have to try to change the system which brings so much suffering to women."

It is unlikely that she learned activism at home. Her mother would not even vote in elections, and voting was practically the only form of activism for her father and grandparents. Yet Sylwia was always socially active, even if it was not associated with feminism at first. "Even when quite young I was active in various social causes (ranging from water in Africa, through protesting against Islamophobia and racism to the cleanup of Jewish cemeteries)." On top of that she was an active girl scout. For eight years, she led the scout team and was the deputy of the commanding officer.

She says: "in a perfect world I could work for a feminist organization all my life but the reality is likely to make it financially impossible. Then I will opt for the IT path." She is sure of one thing: she will continue to be active for two reasons. One is that change will not happen on its own, and the other one is that "I feel best in my life when I can get involved in something." Asked about the qualities that describe her, she replies: "at present it is strong, determined, perseverant, creative, empathic and amiable."

Aleksandra Sobiech has been part of Mamy Głos almost since its beginnings. Currently, she is studying biotechnology at the University of Natural Sciences in Poznań. She has an older brother. Both of them were brought up by their mother, who had to take all the responsibilities associated with sustaining the family and raising children after her husband died. In an interview, Aleksandra repeatedly mentioned her mother as a role model for her social involvement and interest in women's rights. She stressed that her mother never shouted feminist slogans, but she illustrated the power of women with her own life. Not only did she sustain her family, but she also found time for social and political activism. She used to be an active member of the Solidarity movement, and currently she is involved in protests against the changes launched by the government. 
In my case, there wasn't a single trigger. I call it a coincidence which turned out to be destiny. I grew up surrounded by women because my father died when I was quite young, and I had that role model of a mum who sustains the household, does everything, is extremely strong, independent and she really copes. I could not imagine women in another role, because this was the only thing I was familiar with. My mother did not convey feminist thinking to me but she showed me that this could be done.

The second thing Aleksandra mentioned was her participation in a workshop on the image of women in the media, which shook her and encouraged her to become interested in women's issues. She began to read about it and take an interest in the political situation in Poland. She delivered a speech during the first women's strike in Poznań, and again one year later. Although somewhat disappointed by failing to achieve the goals of the strike, she believes that such activity makes sense, especially educational campaigns conducted within the foundation:

This is an even greater motivation to be active, because when we begin at the earlier stage, with the youngest people, they will certainly reject the status quo in the future. They will be aware, they will not pass by, ignore it as insignificant. This also shows me that this rebellion, this fight may be sparked by being peed off, but this is only temporary, while education may be a long-term activity; when we work at the roots and work on it we get results.

Aleksandra is best described as stubborn, which is the first feature she mentions. Then she talks about low self-confidence and low self-esteem, but the third characteristic is openness to people: "I am also a very open person and I love people, I love working with people, talking to them and getting to know them."

Both girls talk about the strong stereotypes surrounding feminism that they had to face. It was difficult to prove to their peer groups that they were regular girls who could be talked to and who were open to different outlooks. The stereotype of a feminist who "is radical, burns bras at protests, shouts at men and will never get a husband" (NB) still lingers on.

They have quite different family experiences. When asked about her parents and their involvement, Natalia says that they are not particularly active, they are typical people. She can recall her grandfather who helped to build a church. Aleksandra talks about her highly active mother, who was involved in the past (the Solidarity movement) and still is today, and her grandpa who was actively working for his community and was one of 
the founders of the housing estate where he lived later, then built a park, and was also politically active.

Before Mamy Głos, Natalia was not very active and she only mentions voluntary work for the Polish Red Cross. Aleksandra went to a sociotherapeutic community center for children with learning problems whom she helped with their homework. In high school, she was a member of the theatrical club and wrote for the school newspaper.

Weronika joined Mamy Głos after it was established. She took part in one of the first workshops organized by the foundation, where she felt very good: "safe, supported, motivated, understood, taken care of and appreciated." This prompted her to return to further workshops and also to begin self-study of feminist/girls' issues. She felt that she would like to be actively involved in propagating these ideas. Although since her childhood she had been brought up in line with the stereotype of a good and nice girl, with time she began to notice the inequalities in how the sexes were treated. Books, films and conversations allowed her to understand what she had come across. Halfway through junior high school, she came to realize that her views and needs were shared by others. This happened after she transferred to a democratic school, as a result of many discussions and books and also thanks to her mother.

In the opinion of Weronika, neither her family nor she noticed the moment when she became involved in Mamy Głos. Her mother's response was favorable and now they go to protests together. Her sister's father was more skeptical, and he even called her a feminazi. The response from her friends was varied; some were positive, some more dismissive. Some were confused and others, especially males, felt somewhat threatened.

Weronika has had some experience with social activism, having taken part in school social campaigns and volunteered for several projects.

Her mother has never been very active politically, but Weronika knows that to some extent she supported her local community and frequently worked for its benefit: "this social element can often be seen in my mom." Weronika has often had opportunities to discuss politics at home. She says that she was impressed by her mother's knowledge and arguments while she had a few political disputes with her sister's father. She describes herself as a "glib person who reads a lot and is intrigued, empathic, a tad ironic, skeptical, considerate and strong." Weronika is in the last year of senior high school. For several years she has been involved in alternative education and democratic schooling. She says that she is not going to pursue higher education because of her dislike for traditional education. 
Her plans for the future are quite clear. She intends to combine her work for Mamy Glos with the empowerment of others, working in the IT sector and writing a blog Zimno tutaj [It's cold here]. Summing up her experience so far, she says: "What I have done so far was quite satisfactory. I feel that people need this and I have no intention of quitting."

\section{Conclusion}

What should be emphasized is the uncanny effectiveness of the campaigns that the foundation has conducted. The girls are successfully tapping into the potential offered by the internet (it is clear that this is their natural environment), but they can also secure financing for their operations. They skillfully use the opportunities offered by organizations that support activism, and they have quickly mastered the art of winning grants and crowdfunding. There are no coincidences in what they do, everything seems to be thought out and secure in legal terms.

Their activities aimed at increasing the activism of young and very young women and increasing their awareness of their rights and potential deserve to be praised. Democracy makes it possible to articulate one's needs and views freely, whether or not they comply with the current government's policies. Mamy Głos has supported the protests associated with changes to the abortion law, but has never made abortion the main topic of its activities. The foundation's fundamental objective is to instill social and political activism in young women and to develop skills which are necessary to undertake different types of activities. Another important apolitical objective is to reinforce the sense of power in girls, which is necessary for them to oppose the various forms of violence which are experienced as early as in junior and senior high school, as evidenced by research. The third objective of utmost importance involves removing barriers to the free selection of education and, consequently, the choice of future career paths taken by women. Stereotypical expectations towards girls and boys translate into attitudes in those around them (school, parents and peers), as well as the students' own choices of educational paths. This results in the feminization or masculinization of certain professions, and further reinforces stereotypes present in society.

The shaping of pro-democratic attitudes promoting activism and equality in both the private and public lives of both sexes at such an early stage might bring positive outcomes in the future. Citizens who are active 
and aware of their rights may sometimes be difficult for the authorities, but they form the foundation of a functioning and mature democracy. The fact that this takes place at such an early and formative age and in a familiar, hence secure, environment additionally increases the impact of the foundation in the analyzed area.

\section{References}

Dolata R., Koseła K., Wiłkomirska A., Zielińska A. (2004), Młodzi obywatele. Wyniki międzynarodowych badań młodzieży, WUW, Warszawa.

Koseła K. (1999), Młodzież szkolna o rynku i demokracji, Oficyna Naukowa, Warszawa.

Kwiatkowska A. (2010), Koncepcja obywatelstwa w teorii feministycznej, in: Praktyki obywatelskie Polaków, ed. J. Raciborski, Wydawnictwo IFiS PAN, Warszawa.

Schultz W., Sibberns H. (eds.) (2004), IEA Civic Education Study. Technical Report.

Szafraniec K. (2011), Wprowadzenie, in: Młodzież 2011, ed. M. Boni, Kancelaria Prezesa RM, Warszawa.

Szafraniec K. (2012), Dojrzewajacy obywatele dojrzewajacej demokracji. O stylu politycznej obecności mlodych, Instytut Obywatelski, Warszawa.

Zalewska A. M., Krzywosz-Rynkiewicz B. (2011), Psychologiczne portrety młodych. Rozwojowe $i$ podmiotowe uwarunkowania aktywności obywatelskiej młodzieży, Wydawnictwo SWPS Academica, Warszawa.

\section{Aktywność fundacji Mamy Głos w kontekście aktywności politycznej młodych}

\section{Streszczenie}

Celem artykułu jest analiza działalności podejmowanej przez fundację Mamy Głos, organizację założoną w 2015 r. przez gimnazjalistki z kilku polskich miast. Posłużą do tego dostępne materiały dotyczące tej organizacji, a także dane zebrane za pomocą wywiadu pogłębionego przeprowadzonego z założycielkami organizacji. Główne pytania badawcze dotyczą motywów aktywności podejmowanej w ramach Mamy Głos, sposobów realizacji zakładanych przez organizację celów, charakterystyki założycielek. Działalność ta zostanie przedstawiona w kontekście aktywności politycznej młodzieży, z uwzględnieniem płci.

Słowa kluczowe: młodzież; Fundacja Mamy Głos; aktywność polityczna 